\title{
MEDICAL STUDENTS BEARING MENTAL STRESS DUE TO THEIR ACADEMIC SCHEDULE
}

\author{
Maria Altaf, KisaF.Altaf, Salman Zahid,Rabia sharf,Ahsan Inayat, Mohammad Owais \& Hisham Usmani.
}

Fatima Jinnah \& Dental College

Dow university of Health Sciences, DUHS

Corresponding Author: maria3188@gmail.com

\begin{abstract}
Medical education is inherently stressful and demanding. Overwhelming burden of information leaves a minimal opportunity to relax and recreate and sometimes leads to serious sleep deprivation. Environmental and social circumstances play a major role in the onset of stress-related diseases. Developing countries share the heavy burden of social and economic challenges. A number of factors-including academic pressure, workload, financial concerns, sleep deprivation, exposure to patients' suffering and deaths, student abuse and a -hidden curriculumll of cynicism have been hypothesized to contribute to this decline in students' mental health. This study determines the rate of anxiety and depression, and the associated social and environmental factors in undergraduate medical students. This study was divided into two measures theoretical problems and academic factors. Randomly data was collected by means of structured close ended questionnaire of 121 students from Fatima Jinnah Dental College(23 boys, 98 girls). Data was analyzed using SPSS 20.0 Factors causing stress in undergraduate medical students was a vast syllabus which makes it difficult for their time management, there was a direct and positive relationship for lack of time for assignments and fear of catching up after a leave.
\end{abstract}

\section{KEYWORDS}

Anxiety, depression, undergraduates medical students, workload, sleep deprivation

\section{INTRODUCTION}

The target of medical education is to grasp knowledgeable, competent, and professional physicians equipped to care for the nation's illness, advance the science of medicine, and to encourage public health, depending on these particular characteristics, one may anticipate medical school would be a time of personal growth, demand, and well-being despite its challenging situation.

Several studies have demonstrated the correlation among stress perception and several factors such as gender, marital status, living environment and academic year (Hendricks, S., et al.1949, Garbee, W et al 1980, Tedesco, L.A., 1986a, Tedesco, L.A et al 1987, Bradley, I et al 1989, Grandy, T. et al 1989, Westerman, G et al 1993, Newton, J.T. et al 1994, Yap, A et al 1996, Heath, J.R et al 1999, Sanders, A et al 1999, Rajab, L., 2001, Acharya, S.H., 2003, Polychronopoulou, A.\&Divaris, K., 2005.). These studies have been repeated in several countries to provewhether different socio-cultural factors affect students' levels of perceived problems.

Unfortunately, studies suggest the modern educational process may have an inadvertent opposing effect on students' mental health, with a high frequency of depression, anxiety, and stress among medical students.( Guthrie EA et al 1995, Moffat KJ 2004, Aktekin M, et al 2001, Guthrie E et al 1998, Givens JL \&Tjia J. 2002, Clark DC \&Zeldow PB. 1988, Rosal MC, et al 1997, Mosley TH Jr 1994, Roberts LW et al 2001, Vitaliano PP et al 1988, Raj SR et al 2000, Ball S, Bax A. 2002, Tyssen R et al 2001, Parkerson GR Broadhead WE \&Tse CK. 1990, Carson AJ, Dias S, Johnston A, et al. 2000, Shanafelt TD et al 2004) It has also been stated that burnout, a measure of distress common among residents and physicians in practice,( Thomas N, Gelfand DV et al 2004, Wolf TM et al 1989) has its origin in medical school.( Krakowski A. 1982, Tedesco, L.A., 1986b)

Over the past decade, dental educators have given rising debate for investigation of stress among dental students within the academic environment. Many authors have endeavor to evaluate the factors perceived as stressful among dental students, while others attempted to document stress symptoms via psychological testing (Tedesco, L.A et al 1987, Bradley, I et al 1989, Grandy, T et al 1989, Tedesco, L.A., 1986a). However many of these studies have followed a strict separation between the assessment of environmental factors involved in the examination of stress and subsequent results (i.e. the so called distress response) the clear distinction between an environmental stressor and distress response is difficult (Miri MR and AkbariBourang M. 2007,Tedesco LA 1986). Furthermore, the initial reaction (response) to an event often serves as new stimuli to elicit further unrest (Tedesco LA 1987).Academic stress is defined as that generated by the proper convenient applications in an academic context along with an individual perception about spending sufficient time to achieve that situation. (Misra $\mathrm{R}$ et al 2000, FernándezBerrocal P et al 2005, Stewart SM et al 1999) Some authors have postulated that psychological distress among students may adversely influence their academic performance,(Spiegel DA 1986, Hojat M 1993, Newbury2001) contribute to academic dishonesty, corruption and misleading.(Fernández-Berrocal P et al. 2005, Stewart SM 1999, Spiegel DA 1986) and play a role in alcohol and substance abuse.(Clark D 1987, Croen LG 1997, Baldwin DC Hughes PH, 1991,Sheehan H 1990,Ball S 2002)

The huge majority of research supporting a correlation among stress and depressive episodes has been based on episodic stressors (discrete events that have a beginning and ending) that have negative or undesirable content. In general, can affect both workers' experience of stress and their psychological and physical health. However, there are some studies which directly create the hazard-stress-harm pathway.

As in previous UK studies there wasn't any discrimination in gender between students on any of the psychological distress questionnaires(Firth J. 1986, Miller PMcC and Surtees PG. 1991). It is clear, however, that later in postgraduate training; female doctors address higher rates of psychological distress than males(Borrill CS 1996). Surtees and Miller (Miller PMcC and Surtees PG. 1991) observed via their study that medical students in their first year of medical training at Edinburgh and found that half disclosed high 
levels of neurotic symptoms at the beginning of the academic year, one-third reporting symptoms at follow-up six months later. Guthrie et al.(Guthrie EA 1995) found strikingly similar rates of psychological morbidity in medical students at Manchester University, with one-third showing evidence of psychiatric morbidity midway through the first year. The Edinburgh study indicated that a small number of students $(n=15,8.6 \%)$ were continuously symptomatic throughout the first year of their training4, and FirthCozens found that $22 \%$ of 302 fourth-year students had psychological symptoms both as students and as house officers, when they were followed up 2 years later5.

Medical schools are demanding: the academic, preclinical and clinical requirements extend students' working hours into nights and weekends (Gabree et al. 1980 and Rajab, L., 2001.). Typical sources of stress for dental students include frequent examinations, examination phobia, reduced leisure time, demanding curricula, requirements to perform specified types and numbers of procedures, anxious patients, time limits, complicated treatments, possible conflicts with patients, fellow students, staff and faculty, lack of selfconfidence, and the differences between the students expectations and reality (Newton, J.T 1994, Heath 1999)

\section{METHODOLOGY AND SUBJECTS}

A cross sectional study was conducted on the undergraduate medical students of Fatima Jinnah dental college and Dow university of health Sciences to get a snapshot view of the prevalence of stress in medical and dental students, and to assess the different perceptions, reasons and coping methods of stress. A total of 121 students participated in the study (The study sample was stratified according to sex, residence (living with parents/ in hostel), and year of study and status of financial assistance from the college. After an in-depth literature review, a semi-structured dental environmental stressquestionnaire (DES) was designed as a tool for data collection. Data collection took one month before their midterms. Data was entered and analyzed with SPSS 0.20

\section{RESULTS}

Questionnaire was distributed to 121 students, 23 were males and 98 were females with mean age of 19.16 and standard deviation of \pm 2.017 . 100 students were living with their parents and 21 were living in hostel or with their relatives living in Karachi.

For the overall problem score, female students had a higher overall mean problem score compared to male students. The students' place of residence showed a statistically significant relationship with the overall problem score; students living with their family reported higher problem levels than other students with different living arrangements. The result of this study shows that students are overburdened with their vast syllabus and assignments with standard deviation of \pm 0.331 and \pm 0.491 and having difficulty grabbing their course after a leave with standard deviation of \pm 0.487 as shown in table number 1

Students with the lowest GPA showed significantly higher overall problem score than those with the highest GPA. The differences in perceived problems among different schools were investigated. Students reported difficulty in getting study materials and fear of parents after failures, time management is being an important stressor amongst them with mean of 1.21. It was observed via results students lack positive feedback from their parents and institution and having fear of unemployment after their studies.

Descriptive Statistics
\begin{tabular}{|l|l|l|l|l|l|}
\hline \multirow{2}{*}{} & N & Sum & \multicolumn{1}{l|}{ Mean } & Std. Deviation \\
\cline { 2 - 6 } & Statistic & Statistic & Statistic & Std. Error & Statistic \\
\hline Syllabus overloaded & 121 & 136 & 1.12 & .030 & .331 \\
Time management & 121 & 146 & 1.21 & .037 & .407 \\
Burden of assignments & 121 & 169 & 1.40 & .045 & .491 \\
Difficulty to grab after leave & 121 & 167 & 1.38 & .044 & .487 \\
Consecutive Lecture & 121 & 168 & 1.39 & .044 & .489 \\
Valid N (listwise) & 121 & & & & \\
\hline
\end{tabular}

Table\# 1: showing academic and theoretical stressors

\section{DISCUSSION}

The inexperienced student community has always been susceptible to stressful life conditions especially in pursuit of higher professional education in a highly competitive environment (World Health Organization, 1994; Saipanis, 2003). A large majority complains itself stressed in the college at one time or another. Medical schools are known to be highly demanding, challenging and stressful learning environments (Polychronopoulou, A.\&Divaris, K., 2005). Contemporary dental curricula require students to attain diverse proficiencies including acquisition of theoretical knowledge, clinical competencies and interpersonal skills (Garbee, W et al 1980, Rajab, L., 2001 and Polychronopoulou, A.\&Divaris, K., 2005).

Identification of potential problems is important in dental education programs as it might give students, faculty and administrators an opportunity to take precautionary measures to prevent dental stress (Yap, A et al 1996). It is assumed that higher levels of perceived student problems lead to more stress (Bradley, I et al 1989). This may indicate that most of the dental students are not well adjusted to the dental school educational environment and to the pressure imposed to fulfill the school requirements.

A recent report, (Lloyd C, Gartrell NK. 1984) confirming earlier studies, (Hunter RCA) (Saslow G. 1956) described particularly high levels of psychiatric distress in medical students in a university in the United States compared with the general population, with 15-20\% of the students meeting criteria for a diagnosis of psychiatric illness. Most studies report a higher prevalence in women than men.( Lloyd C, Gartrell NK, Davidson V. 1978)

Students from different medical schools surveyed in this study, showed differences in their perceived problem levels. Students who have completed their pre-graduation with ' $A$ ' level showed less academic problems as compare to students coming from intermediates.

Studies in the United States suggested that the practice of medicine entails certain risks to the mental health of both qualified physicians (Vaillant G et al 1972, Vincent MO. 1983, McCue JD. 1982) and students,(Pitts FN et al, Lloyd C, Gartrell NK. 1983) and links 
between the training and later problems of mental health have been suggested. (Reibord SP. 1983)

In this study, only students with the lowest GPA experienced marginally statistically significant more perceived problems than students with the highest GPA in overall problem score and the theoretical problem score. This is consistent with the finding of other studies which showed that low academic achievement is characterized by less satisfaction with the education environment (Pimparyon, P., et al 2000, Mayya, S.S.\&, Roff, S., 2004).

Students living with their families had higher overall problem scores, and higher problem scores for the categories of personal and administrative issues and clinical training. These findings may be explained by lack of time and the increased demands of social activities that may limit time in general and lead to a feeling of being overloaded.

\section{Theoretical problems}

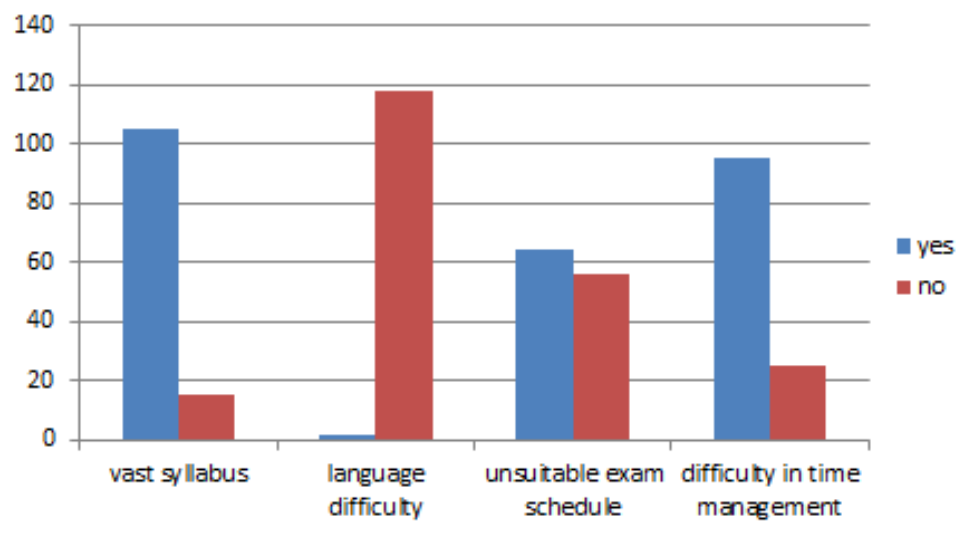

Graph\# 1 showing theoretical stressors

\section{Academic factors}

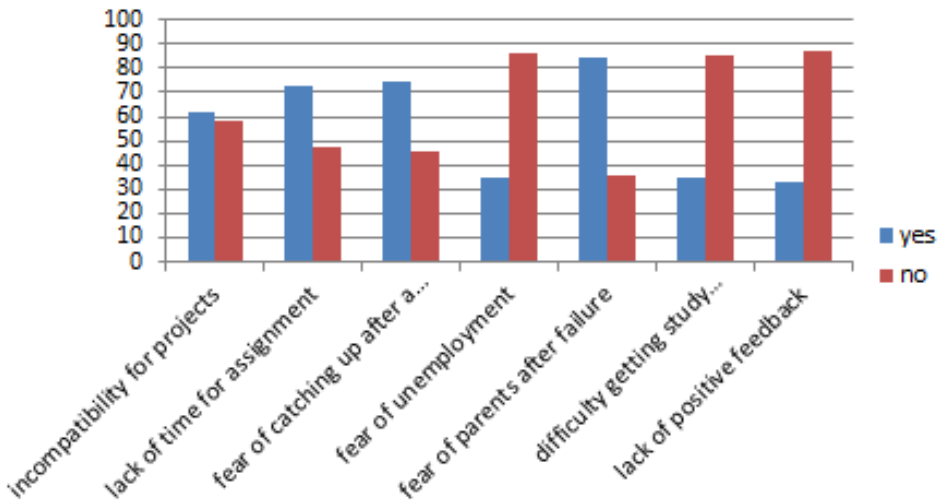

Graph\#2 showing academic stressors

\section{CONCLUSION}

Clinical training was seen to be the highest source of problems. The availability of suitable patients, their compliance with the treatment and student-faculty relationships were the students' main concerns related to their clinical training. This suggested that enhancing and adjusting systems of patient screening and distributing them to different clinical courses, may contribute to possible reduction in the 
perceived problems by the students. The results of the present study showed that the demands and challenges of the profession related to both quality and quantity of academic and practical performance are potent sources of stress.

Both academic and non-academic sources of stress should be considered in curriculum planning and the working environment for dental education. The educational system should deal with the potential stressors for students by stress management programs. Effective assistance from teaching staff, faculty administrators, and families is essential.

\section{REFERENCES}

- Hendricks, S., Joshi, A., Crombie, K., Moola, M., (1949). Perceivedsources of stress among black dental students in South Africa. J. Dent. Educ. 58, 406-410.

- Garbee, W., Zucker, S., Selby, G., (1980). Perceived sources of stress among dental students. J. ADA 100, 853-857.

- Tedesco, L.A., (1986). A psychological perspective on the dental education experience and student performance. J. Dent. Educ. 50, 601-605.

- Tedesco, L.A., Flatow, E., Davis, E.L., Brewer, J.D., Cooper, M.L., (1987). Performance and psychosocial response to the dental school educational experience: exploring barriers to learning. In: Paper presented at the American Association of Dental School Annual Meeting, Chicago, March.

- Bradley, I., Clark, C., Eisner, J., DeGruchy, K., Singer, D.,Hinkleman, K., Gelskey, S., (1989). The student survey of problems in the academic environment in Canadian dental faculties. J. Dent. Educ. 53, 126-131.

- Grandy, T., Westerman, G., ErskineCombs, C., Turner, C., (1989).Perceptions of stress among third-year dental students. J. Dent. Educ. 53, 718-721.

- Westerman, G., Grandy, T., Ocanto, R., Erskine, C., (1993). Perceivedsources of stress in the dental school environment. J. Dent. Educ. 57, 225-231.

- Newton, J.T., Baghalenaini, F., Goodwin, S.R., Invest, J., Lubbouck, M., MaroufSaghakhaneh, N., (1994). Stress in dental school: a survey of students. Dent. Update 5, 162-164.

- Yap, A., Bhole, S., Teo, C., (1996). Across-cultural comparison ofperceived sources of stress in the dental school environment. J. Dent. Educ. 60, 459-464. 88

- Heath, J.R., Mcfarlane, T.V., Umar, M.S., 1999. Perceived sources of stress in dental students. Dent. Update 26, 94-100.

- Sanders, A., Lushington, K., (1999). Sources of stress for Australian dental students. J. Dent. Educ. 63, 688-697.

- Rajab, L., 2001. Perceived sources of stress among dental students at the University of Jordan. J. Dent. Educ. 65, 232-241.

- Acharya, S.H., (2003). Factors affecting stress among Indian dental students. J. Dent. Educ. 67, 1140-1148.

- Polychronopoulou, A., Divaris, K., 2005. Perceived sources of stress among Greek dental students. J. Dent. Educ. 69, 687-692.

- Guthrie EA, Black D, Shaw CM, Hamilton J, Creed FH, Tomenson B. (1995) Embarking upon a medical career: psychological morbidity in first year medical students. Med Educ.; 29:337-41.

- Moffat KJ, McConnachie A, Ross S, Morrison JM. (2004) Firstyear medical student stress and coping in a problem-based learning medical curriculum. Med Educ.;38:482-91.

- Aktekin M, Karaman T, Senol YY, Erdem S, Erengin H, Akaydin M. (2001) Anxiety, depression and stressful life events among medical students: a prospective study in Antalya, Turkey. Med Educ.;35:12-17.

- Guthrie E, Black D, Bagalkote H, Shaw C, Campbell M, Creed F.( 1998) Psychological stress and burnout in medical students: a five-year prospective longitudinal study. J R Soc Med.;91:23743
- Givens JL, Tjia J.( 2002) Depressed medical students' use of mental health services and barriers to use. Acad Med.;77:918-21.

- Clark DC, Zeldow PB. (1988) Vicissitudes of depressed mood during four years of medical school. JAMA.;260:2521-28.

- Rosal MC, Ockene IS, Ockene JK, Barrett SV, Ma Y, Hebert JR. (1997) A longitudinal study of students' depression at one medical school. Acad Med;72:542-46.

- Mosley TH Jr, Perrin SG, Neral SM, Dubbert PM, Grothues CA, Pinto BM. (1994) Stress, coping, and well-being among thirdyear medical students. AcadMed ;69: 765-67.

- Roberts LW, Warner TD, Lyketsos C, Frank E, Ganzini L, Carter D. (2001) Perceptions of academic vulnerability associated with personal illness: a study of 1,027 students at nine medical schools. Collaborative Research Group on Medical Student Health. ComprPsychiatry ;42:1-15.

- Vitaliano PP, Maiuro RD, Russo J, MitchellES, Carr JE, Van Citters RL. (1988) A biopsychosocial model of medical student distress. J BehavMed ;11:311-31.

- Raj SR, Simpson CS, Hopman WM, Singer MA. (2000) Healthrelated quality of life among final-year medical students. CMA J.; 162:509-10.

- Ball S, Bax A. (2002) Self-care in medical education: effectiveness of health-habits interventions for first-year medical students. AcadMed ;77:911-917.

- Tyssen R, Vaglum P, Gronvold NT, Ekeberg O. (2001)Suicidal ideation among medical students and young physicians: a nationwide and prospective study of prevalence and predictors. $\mathbf{J}$ Affect Disord;64:69-79.

- Parkerson GR Broadhead WE, Tse CK. (1990).The health status and life satisfaction of first-year medical students. Acad Med;65:586- 88.

- Carson AJ, Dias S, Johnston A, (2000) Mental health in medical students: a case control study using the 60 item General Health Questionnaire. Scott Med J;45:115-16.

- $\quad$ Shanafelt TD, Bradley KA, Wipf JE, Back AL. (2004) Burnout and self-reported patient care in an internal medicine residency program. Ann Intern Med. March 5.2002;136:358-67.

- Thomas N. Resident burnout. JAMA; 292:2880-89.

- Gelfand DV, Podnos YD, Carmichael JC, Saltzman DJ, Wilson SE, Williams RA. (2004) Effect of the 80-hour workweek on resident burnout. Arch Surg.;139:933-38; discussion 938-40.

- Wolf TM, Balson PM, Faucett JM, Randall HM. (1989).A retrospective study of attitude change during medical education. Med Educ;23:19-23.

- Krakowski A. (1982) Stress and the practice of medicine: the myth and the reality. J Psychosom Res.;26:91-98.

- Tedesco, L.A., (1986). The etiology of survival: a psychological perspective on the dental school experience. In: Paper presented at the American Association of Dental Schools Annual Meeting, Washington DC, March

- Tedesco, L.A., Flatow, E., Davis, E.L., Brewer, J.D., Cooper, M.L., (1987). Performance and psychosocial response to the dental school educational experience: exploring barriers to learning. In: Paper presented at the American Association of Dental School Annual Meeting, Chicago, March.

- Bradley, I., Clark, C., Eisner, J., DeGruchy, K., Singer, D., Hinkleman, K., Gelskey, S., (1989). The student survey of problems in the academic environment in Canadian dental faculties. J. Dent. Educ. 53, 126-131.

- Grandy, T., Westerman, G., ErskineCombs, C., Turner, C., (1989). Perceptions of stress among third-year dental students. J. Dent. Educ. 53, 718-721.

- Tedesco, L.A., (1986). A psychological perspective on the dental education experience and student performance. J. Dent. Educ. 50, 601-605.

- Miri MR, AkbariBourang M. (2007).The correlation between emotional intelligence and school anxiety among high school students in South Khorasan. J BirjandUniv Med Sci.;14:54-9. 
- $\quad$ Misra R, McKean M, West S, Russo T. (2000). Academic stress of college students: Comparison of student and faculty perceptions. Coll Stud J ;34:236-45.

- Fernández-Berrocal P, Salovey P, Vera A, Extremerta N, Ramos N. (2005) Cultural influences on the relation between perceived emotional intelligence and depression. RIPS/IRSP;18:91-107.

- Stewart SM, Lam TH, Betson CL, Wong CM, Wong AM. (1999). A prospective analysis of stress and academic performance in the first two years of medical school. Med Educ;33:243-50.

- $\quad$ Spiegel DA, Smolen RC, Hopfensperger KA. (1986). Medical student stress and clerkship performance. J Med Educ;61:929-31.

- Spiegel DA, Smolen RC, Jonas CK. (1986). An examination of the relationships among interpersonal stress, morale and academic performance in male and female medical students. SocSci Med.;23:1157-61.

- Hojat M, Robeson M, Damjanov I, Veloski JJ, Glaser K, Gonnella JS. (1993). Students' psychosocial characteristics as predictors of academic performance in medical school.Acad Med.;68:635-37.

- Newbury-Birch D, Walshaw D, Kamali F.( 2001).Drink and drugs: from medical students to doctors. Drug Alcohol Depend;64: 265-70.

- Clark D, Eckenfels EJ, Daugherty SR, Fawcett J. (1987). Alcohol-use patterns through medical school. A longitudinal study of one class. JAMA.;257:2921-26.

- Croen LG, Woesner M, Herman M, Reichgott M. (1997). A longitudinal study of substance use and abuse in a single class of medical students. Acad Med;72:376-81.

- Baldwin DC Hughes PH, Conard SE, Storr CL, Sheehan DV. (1991). Substance use among senior medical students. A survey of 23 medical schools. JAMA;265:2074-78.

- Sheehan H, Sheehan D, White K, Leibowitz A, Baldwin DC Jr. (1990). A pilot study of medical student 'abuse': student perceptions of mistreatment and misconduct in medical school. JAMA.;263:533-37.

- Ball S, Bax A. (2002). Self-care in medical education: effectiveness of health-habits interventions for first-year medical students. Acad Med.;77:911-917.

- Firth J. (1986). Levels and source of stress in medical students. BMJ:292:1177-80

- Miller PMcC, Surtees PG. (1991). Psychological symptoms and their course in first-year medical students as assessed by the
Interval General Health Questionnaire (I-GHQ). BrJ Psychiatry;159: 199-207

- Borrill CS, Wall MA, West GE, et al. (1996). Mental Health of the Workforce in NHS Trusts. Final Report. Sheffield: Institute of Work Psychology, University of Sheffield/Leeds: Department of Psychology, University of Leeds,

- Guthrie EA, Black D, Shaw CM, Hamilton J, Creed FH, Tomenson B. (1995). Embarking upon a medical career: psychological morbidity in first year medical students. Med Education;29:337-41

- $\quad$ Lloyd C, Gartrell NK. (1984). Psychiatric symptoms in medical students. Compr Psychiatry;25: 552-65.

- Hunter RCA, Prince RH, Schwartzman AE. Comments on emotional disturbances in a medical undergraduate population.JAMA 1;83:989-92.

- Saslow G. (1956). Psychiatric problems of medical students. J Med Educ;31:27 33.

- Lloyd C, Gartrell NK. (1981)Sex differences in student mental health. Am J Psychiany;138: 1346-51.

- Davidson V. (1978). Coping styles of women medical students. J Med Educ;53:902-7.

- Pimparyon, P., Roff, S., McAleer, S., (2000). Educational environment, students' approaches to learning and academic achievement in a Thai nursing school. Med. Teach. 22, 359-364.

- Mayya, S.S., Roff, S., (2004). Students' perceptions of educational environment: a comparison of academic achievers and underachievers at Kasturba Medical College, India. Educ. Health 17, 280-291.

- Vaillant G, Sobowale D, MacArthur C. (1972). Some psychological vulnerabilities ofphysicians. NEnglJMed;278:3725.

- Vincent MO. (1983). Some sequelae of stress in physicians. PsychiarJUnivOtawa;8:120-4.

- McCue JD. (1982). The effects of stress on physicians and their medical practice. N Engl J Med;306:458-63.

- Pitts FN, Winokur, G, Stewart MA. Psychotic syndromes, anxiety symptoms, and response tostress in medical students. AmJPsychiany 11;118:333-40.

- Lloyd C, Gartrell NK. (1983); A furtherassessmentofmedical student stress.J7MedEduc 58:964-7.

- Reibord SP. (1983). Psychological perspectives on iatrogenic physician impairment. Pharos;Summer:2-8. 